\title{
Analysis of the Main Causes of the Successful Development of German Football and Its Enlightenment to China
}

\author{
Ming $L u^{1, a}$ \\ ${ }^{1}$ Baicheng Normal University, Baicheng, Jilin, 137000 \\ a email
}

Keywords: German Football, Successful Development, Enlightenment

\begin{abstract}
This paper explores the factors of the rise of German football from the perspectives of culture, system, talent and media. It is pointed out that the rise of German football lies in the influence of Germanic culture on football style and shaping, the German Football Association (DFB) and the German Football League (DFL) collaborative management, combined with the training of young people under the reserve personnel training system and training concept, the German television media and football effective "marriage." China's football must return to education, reform and promote the development of campus football; pay attention to the construction of football culture, the development and popularization of social football, to enhance the culture of football consciously; actively bid for international large-scale football events; the introduction of football tournament market competition mechanism strategy.
\end{abstract}

\section{Introduction}

Germany is the world's undoubtedly strong football, the German football's strong performance in two areas, one, the domestic high level of professional league, especially the German Football League, is one of the five major European league; German football national team won four World Cup and three European championship, especially in 2014 Brazil World Cup, the German team became the first in the Americas won the World Cup championship European team. Tracing the history of Germany for half a century and found that German football has also experienced a long and difficult growth process, its success behind both the German football unique technical and tactical style, diversity of social support, the government's strong funding and management, But also reflects the political, economic, national, cultural, institutional, talent, media and other factors, under the influence of these factors, the German football successfully out of the sink and the doldrums of the quagmire, and ultimately to achieve the rise. German football is growing under the influence of multiple factors, this study mainly from the culture, system, talent, media, four dimensions to explore the reasons for the successful rise of German football, with a view to the revitalization of China's football benefit.

\section{The Successful Rise of German Football and Its Reasons}

German football and its national culture and deep national characteristics are closely related, whether it is team building or organizational development, football culture as its magic weapon to win. In the long historical process, the Germans gradually developed a unique national character, this "cultural power" is mainly reflected in the discipline, pay attention to order, pay attention to decent, full of confidence, high emotion, tenacious and so on. The reason why German football has maintained a long history of glory, and the German national culture unique tenacious will and almost perfect organizational discipline inseparable. Germanic nation neither overbearing national character achievements of the German football, so that Germany 4 degrees standing on the World Cup top podium, repeatedly at a critical moment to win. For the Germans, football is also as strict as their national discipline, and this feature has always run through the player's life, training and competition, and the German national character shown in the obedience of discipline, unity and cooperation, Pay attention to the order of the national character consistent. German football is a kind of strength football, but the game not only rely on the power, but also the pursuit of adequate 
physical fitness, technical perfection, tactical cooperation, discipline and morale of the tenacious. German football players meticulous collective spirit, Jagged play, dare to dare to grab the image of the tough guy to the Germanic nation neither humble nor humble fighting spirit embodied most vividly. Team, discipline, mentality, action a high degree of unity of technical and tactical character is the best character of the German football cultural portrayal. Strong collective spirit of the formation of the German football as a whole, the whole attack on the tactical style is the embodiment of the collective spirit. German national anthem "Germany, Germany above all else" so that the entire Germanic people firmly in the together, resulting in a sense of collective honor so that each player is convinced that will not lose any teams, so that players in the psychological and momentum Take advantage of the overall awareness of the importance of the team's stability, the player's average combat capability is improved. And, the German football pay attention to unity, from the coach to the players, from the old players to the new players, no matter at any time, as long as the country needs, each team can absolutely obey the arrangements, for the honor of Germany and hard work. It is this spirit derived from the national spirit of the team, discipline, created a strong German football cohesion and combat effectiveness. For Germany, football is not just a simple sport, has gradually evolved into the essence of social and cultural sustenance, as well as the realization of the German national cultural identity of the important way.

German football attaches importance to the cultivation of young talent reserve personnel, with a systematic science of youth training system. Mainly from the professional football club, campus football and genius training center 3 areas to complete the reserve personnel training, and schools, clubs and local Football Association in close cooperation, constitute a systematic scientific management system. This cooperative model can coordinate the relationship between school culture learning, sports training and competition, so that the education of school culture and the rational training of the club is always accompanied by the growth of young people. German Football Association to strengthen cooperation with the club, the school, each professional club athletic center has its own boarding school, equipped with specialized teachers to teach players culture class.

The rise of German football, in addition to advanced training concepts, deep cultural heritage, offensive and defensive balance of technical style, scientific youth training system, but also benefit from the new media fueled. Germany is one of the most developed countries in the global media, Germany's sports media is almost accompanied by the start of the TV. Germany's sports television media to television and football two cultural areas as the core, with competition and checks and balances, a high degree of autonomy, public welfare and other characteristics. Football is the favorite sports of the German people, people like to play football, talk about football and watching football, football is Germany's highest ratings of sports.

The rise of German football is in the process of professionalization of the German Football Association and the German Football League under the coordinated management of the realization. 2001 "German Football League" was established, the Union is the Bundesliga, Germany B two major professional league members of the service providers, mainly on behalf of various types of teams dealing with the game, public and media related matters. Including the operation and management of the two-stage professional league, every season TV, radio, Internet broadcast and brand promotion, the Football League is a highly professional product of the German Football League. After the establishment of the German Football League and no monopoly on power, but actively cooperate with the German Football Association, the co-management of football. Including the reform of the club's operations and entry authorization; the reform of the professional league team's entry license system; to strengthen the professional club youth team training; audit club finance, to ensure that each team in the league has enough mobility Capital to maintain the operation; to build a genius training center to ensure the continuation of the reserve talent team; standard football rules and regulations, improve the legal construction, the German football to lead the rules to follow the law of the "rational kingdom." 


\section{Enlightenment to Chinese Football Reform}

The development of any sport must have its own specific space and cultural soil, the development of football can not be separated from the culture of culture, culture is the fundamental survival of football. Chinese football since the implementation of the professional league since 1994, the development of slow, achieved little success, the other side of the fighting, violations of officials, strike, field gambling, team contradictions and other discordant phenomenon, there is " "Culture" of the black whistle, lack of cultural integrity, match-fixing and other "alienation" phenomenon is serious, lack of cultural awareness of football in China. Development and popularization of social football, to build a healthy social football culture is an important path for the development of Chinese football. Now, we should start from our country's cultural foundation and national conditions, cultivate football culture suitable for their own characteristics.

Teenage football reserve personnel training is slow, long cycle of systems engineering, youth soccer players first students, followed by athletes, culture classes and football training for players is equally important. Only let the players get the school education, in order to lay a solid cultural foundation. "Chinese football in the future should be like football developed countries, college players, players are also college students". China's football to achieve sustainable development, we must make football reserve personnel training to return to education, the development of campus football is the key to the rise of Chinese football. Therefore, we must reform and promote the development of campus football, play football education function, the campus football as the expansion of football population, promote the healthy growth of young people based on the project. Therefore, the first, do a good job on the campus football development plan, improve through the university, high school, junior high school, primary school 4 football competition system, and strengthen the effective convergence between the system, and gradually establish and improve the four-level football league mechanism, breaking the "fixed school" Fence, to promote the establishment of large and medium primary school football team, in full of competition in the healthy competition to promote the sustainable development of campus football. Second, vigorously support the characteristics of small and medium football schools, promote the popularization of campus football, deepen the reform of school sports, primary and secondary schools should be included in the teaching of football content, promote youth culture and football skills and common development. To improve the examination enrollment policy, to strengthen the campus football teacher training, to enhance the level of campus football security, encourage students to actively participate in long-term football learning and after-school training. Third, combined with China's national conditions, adhere to the "combination of physical and educational" development path, strengthen the school education and professional football club organic combination, the establishment of a stable school football training system, so that more young people understand football, soccer, To promote the growth of campus football talent, the real school to become a football talent "reservoir." "China's World Cup qualifying, hosting the World Cup and won the World Cup champion is his three wishes." Facing the embarrassment of our football performance. "China's World Cup qualifying, hosting the World Cup and won the World Cup champion is his three wishes." China's football performance in the face of embarrassment Dilemma, China needs to actively bid for international large-scale football events, the need to host the World Cup and other large sports events to resolve the plight of China's football, to re-evoke the enthusiasm of the Chinese football and confidence, so as to crack the Chinese football out of the quagmire, to the world's problems. Therefore, we should rationally deal with the international questioning and speculation, the objective face of the Football World Cup and other games on the impact of our football and strategic value, and actively bid for international large-scale football tournament.

\section{Conclusion}

Germany is the world's undoubtedly strong football, has won four World Cup and three European championships, the German football has achieved great success. Juvenile football is the basis for the 
successful rise of German football, a complete reserve athlete training system, a unique talent development program, advanced youth training ideas are important to the success of German football protection. Under the background of the introduction of the overall plan of China's football reform, the author analyzes the factors of the successful development of German youth soccer from the perspectives of culture, system, talent and media, with a view to the benefit of the youth football in China.

\section{Acknowledgements}

Jilin province education science "thirteen five" planning key topic: "Baicheng youth football development research", the subject number: ZD16054, the project leader: Lu Ming, Baicheng Normal University.

\section{References}

[1] Wang Xihong. Changchun University football teaching curriculum reform and opportunities [J]. Henan Science and Technology.

[2] Shao Yuan. Analysis of the impact of college football coaches ability to coach the factors [J]. Modern communication.

[3] Shao Yuan. The college football training training in the development of joint training model [J]. Modern communication.

[4] Qiao Jianping.Study on the Feasibility of Offering Soccer Clubs in Inner Mongolia Colleges and Universities [J] .An yinhan, 2017 (04)

[5] Jiang Guangyi. On the campus football soft environment system construction [J]. Journal of Shenyang Physical Education Institute, 2017 (03)

[6] Wu Jia Dong. Analysis of media reports on the impact of football fans words and deeds [J]. Today media, 2017 (03) 